\title{
Soil temperature prediction from air temperature for alluvial soils in lower Indo-Gangetic plain
}

\author{
D. Barman ${ }^{1}$, D.K. Kundu', Soumen Pal ${ }^{2}$, Susanto Pal ${ }^{1}$, A.K. Chakraborty ${ }^{1}$, A.K. Jha \\ S.P. Mazumdar ${ }^{1}$, R. Saha ${ }^{1}$, and P. Bhattacharyya ${ }^{1}$ \\ ${ }^{1}$ ICAR-Central Research Institute for Jute and Allied Fibres, Barrackpore, Kolkata-700 120, West Bengal, India \\ ${ }^{2}$ ICAR-Indian Agricultural Statistics Research Institute, New Delhi-110 012, India
}

Received August 31, 2016; accepted January 25, 2017

\begin{abstract}
A b s t r a c t. Soil temperature is an important factor in biogeochemical processes. On-site monitoring of soil temperature is limited in spatio-temporal scale as compared to air temperature data inventories due to various management difficulties. Therefore, empirical models were developed by taking 30-year long-term (1985-2014) air and soil temperature data for prediction of soil temperatures at three depths $(5,15,30 \mathrm{~cm})$ in morning (0636 Indian standard time) and afternoon (1336 Indian standard time) for alluvial soils in lower Indo-Gangetic plain. At $5 \mathrm{~cm}$ depth, power and exponential regression models were best fitted for daily data in morning and afternoon, respectively, but it was reverse at $15 \mathrm{~cm}$. However, at $30 \mathrm{~cm}$, exponential models were best fitted for both the times. Regression analysis revealed that in morning for all three depths and in afternoon for $30 \mathrm{~cm}$ depth, soil temperatures (daily, weekly, and monthly) could be predicted more efficiently with the help of corresponding mean air temperature than that of maximum and minimum. However, in afternoon, prediction of soil temperature at 5 and $15 \mathrm{~cm}$ depths were more precised for all the time intervals when maximum air temperature was used, except for weekly soil temperature at $15 \mathrm{~cm}$, where the use of mean air temperature gave better prediction.

$\mathrm{K}$ e y w o r d s: soil temperature, air temperature, regression analysis, alluvial soil, Indo-Gangetic plain
\end{abstract}

\section{INTRODUCTION}

Soil temperature is an important factor in seed germination (Dwyer et al., 1990), root growth (Kaspar and Bland, 1992), root respiration (Burton et al., 1998), and water and nutrient uptake by plants (Kaspar and Bland, 1992). It also influences biological processes of soil inhabitants like insects and other soil organisms (Kluender et al., 1993; McCann et al., 1991). It directly and indirectly affects soil physical processes like infiltration (Singh, 1992), hydraulic conductivity (Ren et al., 2014), and movement

*Corresponding author e-mail: dbarman.icar@gmail.com of nutrients and chemicals (solute movement) in soil profiles (Grundmann et al., 1995; Vigil and Kissel, 1995). As solute concentration is affected by soil temperature, it controls their movements in soils (Merdun, 2012). Apart from this, soil temperature controls biogeochemical processes such as dissolved organic carbon export (Haei et al., 2010), its residence time in soils (Euskirchen, 2006; Oquist and Laudon, 2008), rates of mineralization (Haei et al., 2013; Rustad et al., 2001) and/or decomposition of soil organic matter (Davidson and Janssens, 2006; Domisch et al., 2001; Melillo et al., 2002) as well as forest productivity (Stromgren and Linder, 2002). Soil temperature has a direct relationship with decomposition of organic matter and soil respiration (Leirós et al., 1999). Considering its significant contribution in soil weathering process, soil temperature regime has been included as classification criteria in the Soil Taxonomy (Gislason et al., 2009; Soil Survey Staff, 1999).

Air temperature is one of the important climatic parameters, which is directly related to soil temperature. It has been observed that the global worming effects is not only restricted to air temperature but also change soil temperature as well as precipitation patterns (Jungqvist et al., 2014). As the soil temperature is influenced by various soil and moisture regimes and vis-a-versa, its response to climate change differs from that of air temperature (Zhang et al., 2005). At the same time, studies on climate change and carbon sequestration also need reliable data on soil temperature (Brenna et al., 2002). As the measurement of soil temperature is limited in spatio-temporal scale, air temperature has often been used to estimate soil temperature by several researchers 
(Gupta et al., 1983; Hasfurther and Burman, 1974; Toy et al., 1978; Zheng, 1993). Soil temperature although integral in many biogeochemical processes in ecosystem, is often difficult to monitor in spatio-temporal levels as installation of soil temperature measuring equipment in soil profile not only a costly affair but also tedious. Developing suitable site specific model to predict soil temperature from air temperature could decrease the amount of time, energy, and cost necessary for on-site monitoring of soil temperature. Empirical model fairly predicts soil temperature from air temperature along with some related parameters (Kang et al., 2000), but it requires to develop for specific sites considering prevailing soil moisture, land use and climate condition. In addition, linking of soil and air temperature data of permanent weather station envisaged understanding of temporal and spatial variation in soil temperature in relation to climate change pattern. Keeping this in view the objective of this study was to develop suitable regression model to estimate and predicts the soil temperatures at different soil depths by using the long-term air temperature data.

\section{MATERIALS AND METHODS}

The study site falls under new alluvial zone (soil type: Ustocrept) which is one of the six agro-climatic zones, viz. hill zone, terai zone, old alluvial zone, new alluvial zone, red and laterite zone, and coastal and saline zone in West Bengal (eastern state) of India. The long-term average annual rainfall (1976-2015) at the site was $1552.3 \mathrm{~mm}$ (ranges between 923.9 and $2253.6 \mathrm{~mm}$ ), $73.3 \%$ of which precipitated during the months of June to September (monsoon), $14.3 \%$ during March to May (pre-monsoon), $10.2 \%$ during October to December (post-monsoon) and 2.2\% during January to February (winter). The mean annual maximum and minimum temperatures were 31.1 and $20.8^{\circ} \mathrm{C}$, respectively. The climate of the study site is subtropical and humid.

Long-term data of air and soil temperature for the period of 30 years (1985-2014) were collected from the Agrometeorology Section of ICAR-Central Research Institute for Jute and Allied Fibres (ICAR-CRIJAF), Barrackpore, Kolkata. The agrometeorological observatory is situated at $22^{\circ} 45^{\prime} 16.53^{\prime \prime} \mathrm{N}$ and $88^{\circ} 25^{\prime} 19.25^{\prime \prime} \mathrm{E}$ and $9.69 \mathrm{~m}$ above mean sea level. Stevenson screen installed at $1.2 \mathrm{~m}$ height was used to record air temperature data, and bare soil temperature data were recorded with mercury soil thermometers installed at 5, 15, and $30 \mathrm{~cm}$ soil depths. Both air and soil temperatures data were recorded daily at two fixed times, first was in the morning at 0636 IST and second one in the afternoon at 1336 IST. The morning reading represented the minimum and the afternoon reading to the maximum values of temperature. Daily data of soil temperatures at three depths $(5,15$, and $30 \mathrm{~cm})$ and air temperatures were converted to weekly, monthly, and annual means by recommended statistical analysis. Soil tem- perature data were taken up to $30 \mathrm{~cm}$ depth because temperature changes primarily occurred within that depth of soil in a temporal and spatial scale, while beyond 40-60 cm soil depth the change in soil temperature becomes non-significant (Scheffer et al., 2002).

Soil samples at 5, 15, and $30 \mathrm{~cm}$ depths were collected from four random points within $1 \mathrm{~m}$ radius circle by keeping soil thermometers at or near the centre of the circle. The composite soil samples for each soil depth were made by quartering method and air dried. Air dried samples were passed through $2 \mathrm{~mm}$ sieve before analysis of soil texture in laboratory by following hydrometer method (Bouyoucos, 1962). Sand, silt, and clay percentages in soils were 26.04, 56.16, and 7.80 at $5 \mathrm{~cm}$ depth; 42.04, 36.08, and 21.88 at $15 \mathrm{~cm}$ depth; and 49.96, 26.08, and 23.96 at $30 \mathrm{~cm}$ depth, respectively. The corresponding textural classes were silty loam, loam, and sandy loam at 5, 15, and $30 \mathrm{~cm}$ depths, respectively.

The mean, standard deviation and coefficient of variation were calculated by using the following equations:

$$
\begin{gathered}
T_{m}=\sum\left(X_{i} / n\right), \\
\sigma=\sqrt{ }\left[\left\{X_{i}-\left(\sum\left(X_{i} / n\right)\right\}^{2} / n\right],\right.
\end{gathered}
$$

coefficient of variation $(\mathrm{CV}, \%)=(\sigma / \mathrm{Tm}) 100 \%$,

where: $T_{m}$ is the mean air or soil temperature, $X_{i}$ is the air or soil temperature of i number of weeks, months, seasons or years, $(\mathrm{i}=1,2 \ldots n) ; n$ is the total number of weeks, months, seasons or years for which temperature data is being analyzed; $\sigma$ is standard deviation of i numbers of time period.

In this study, the magnitude of trend in the temperature time series was determined using a non-parametric method (Theil, 1950) known as Theil-Sen estimator or Sen slope estimator (Sen, 1968). Sen method assumes a linear trend in the time series and has been widely used for determining the magnitude of trend in hydro-meteorological time series (Kumar et al., 2014; Pal et al., 2015). By using this method, the true slope (change per unit time) can be estimated by using a simple non-parametric procedure. To derive an estimate of the slope in a linear model:

$$
f(t)=Q t+\mathrm{B},
$$

where: $\mathrm{B}$ is a constant, the slopes of all data pairs are calculated as:

$$
Q_{i}=\frac{x_{j}-x_{k}}{j-k}, i=1,2, \ldots, N
$$

where: $x_{j}$ and $x_{k}$ are data values at time, $j$ and $\mathrm{k}(j>k)$, respectively. The median of these $N$ values of $Q_{i}$ is Sen estimator $(Q)$ of slope. A positive value of $Q$ indicates an upward (increasing) trend and a negative value indicates a downward (decreasing) trend in the time series. 
To determine whether the trend obtained from Sen slope estimator is statistically significant or not, non-parametric Mann-Kendall (M-K) test (Kendall, 1975; Mann, 1945) was employed in the present study. According to this test, the null hypothesis $H_{0}$ assumes that there is no trend. The alternative hypothesis $H_{1}$ is that the data follow an increasing or decreasing monotonic trend over time. If a data value from a later time period is higher (lower) than a data value from an earlier time period, the $\mathrm{M}-\mathrm{K}$ statistic is incremented (decremented) by 1 . The standard test statistic $Z$ was computed and was approximately normally distributed. The presence of a statistically significant trend was evaluated using the $Z$ value. A positive (negative) value of $Z$ indicates an upward (downward) trend. If the computed value of $|Z|>Z_{\alpha / 2}$, the null hypothesis $\left(H_{0}\right)$ is rejected at $\alpha$ level of significance in a two-sided test. The corresponding $\mathrm{p}$ value was calculated at 5\% significance level.

Different non-linear statistical models were used to predict soil temperature $\left(Y_{t}\right)$ at time point $t=1,2, \ldots n$ using air temperature as the predictor variable. By this way, we obtained predicted soil temperature $\left(\hat{Y}_{t}\right)$ at all the time points for the power, exponential and logarithmic models. The lower and upper limits of prediction interval for all the observations were computed statistically at $95 \%$ confidence level.

\section{RESULTS AND DISCUSSION}

The characteristics of both air and soil temperatures were analyzed for daily, weekly, and monthly data to develop their corresponding relationships. The average of 30 years (1985-2014) of daily minimum, maximum, and mean air temperatures followed the similar pattern (Fig. 1). The scrutiny of 30 years averaged daily air temperature data showed that the lowest minimum, maximum, and mean temperatures were $10.05,23.69$, and $16.88^{\circ} \mathrm{C}$, respectively and their respective highest values were $26.54,36.47$, and $31.09^{\circ} \mathrm{C}$. The coefficients of variation $(\mathrm{CV})$ for minimum air temperature were higher (ranged from 2.82 to $32.93 \%$ ) than that of maximum air temperature (ranged from 3.53 to $11.85 \%$ ), which indicated that maximum temperatures over the last three decades were more consistent than minimum temperature. When daily air temperature data were converted to weekly time scale by statistical mean, its 30 years average data also showed the similar trend like daily data. Weekly lowest minimum $\left(10.41^{\circ} \mathrm{C}\right)$, maximum $\left(23.95^{\circ} \mathrm{C}\right)$, and mean $\left(17.18^{\circ} \mathrm{C}\right)$ air temperatures were observed at first week (1-7 January) of a calendar year, whereas highest values for both the minimum $\left(25.95^{\circ} \mathrm{C}\right)$ and mean $\left(30.71^{\circ} \mathrm{C}\right)$ temperatures were found at 22 nd week ( 28 May to 3 June) but for maximum $\left(35.85^{\circ} \mathrm{C}\right)$ it was at 16 th week $(16-22$ April). Similar to the variability of daily air temperature, $\mathrm{CV}$ values of weekly minimum temperature were higher (ranged from 2.01 to $21.72 \%$ ) than that of maximum temperatures (2.44 to $7.51 \%)$. Among the 52 weeks in a year,

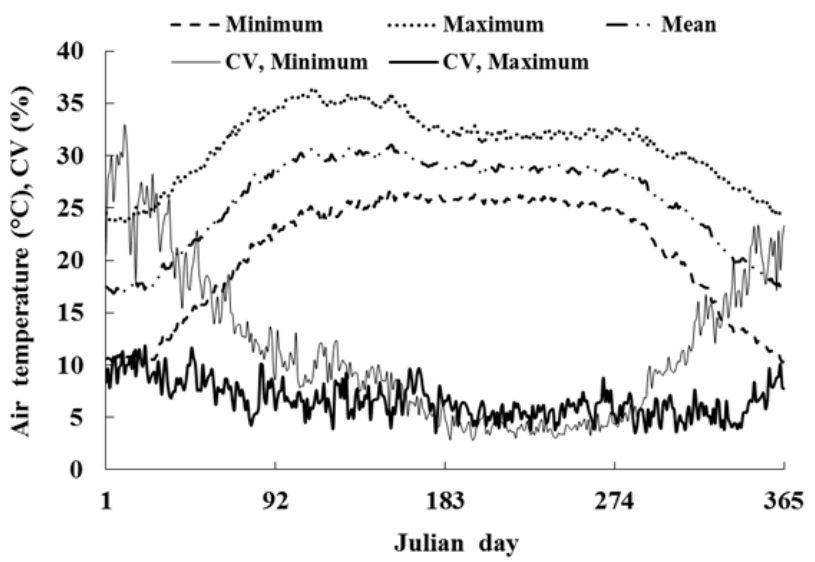

Fig. 1. Daily air temperature pattern of 30 years average data (1985-2014) with their coefficient of variation in lower IndoGangetic plain.

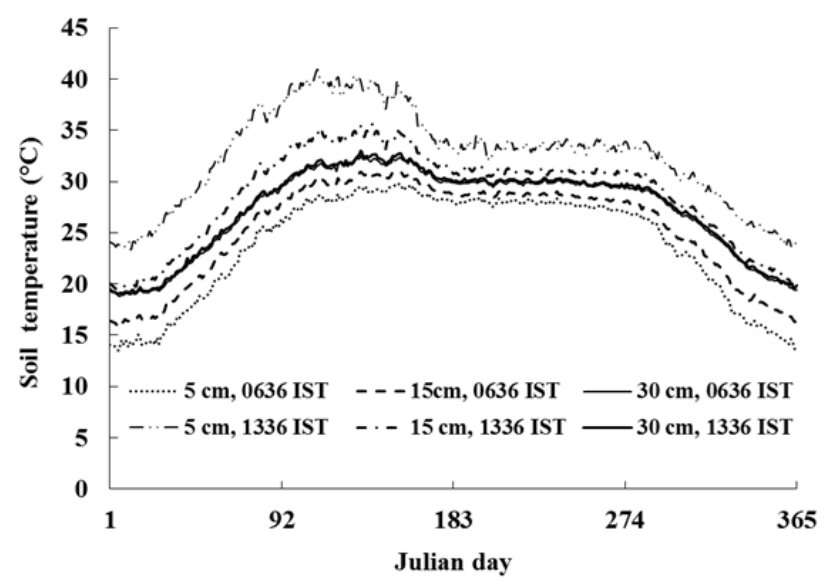

Fig. 2. Daily soil temperature pattern in morning (at 0636 IST) and afternoon (at 1336 IST) at different depths for alluvial soils in lower Indo-Gangetic plain.

the $\mathrm{CV}$ values of minimum and maximum air temperature were respectively lowest on 27th week (2-8 July) and 29th week (16-22 July) because during this period air temperature fluctuation was lesser than rest of a year due to the south-west monsoon rain that generally starts on about 2 nd week of June (Barman et al., 2012).

Like daily air temperature average of 30 years daily soil temperatures at each depth of 5,15 , and $30 \mathrm{~cm}$ in morning (at 0636 IST) and afternoon (at 1336 IST) plotted against the days of year and it was found that soil temperature followed the similar pattern of air temperature (Fig. 2). However, the magnitude of soil temperatures were different than that of air temperature; average daily soil temperatures at 5,15 , and $30 \mathrm{~cm}$ soil depths in morning were about 2.97, 4.51, and $6.30^{\circ} \mathrm{C}$ higher, respectively, than minimum air temperature, whereas in afternoon soil temperatures were $1.48^{\circ} \mathrm{C}$ higher at $5 \mathrm{~cm}$ but 2.25 and $3.62^{\circ} \mathrm{C}$ lower, respectively at 15 and $30 \mathrm{~cm}$ soil depths than corresponding maximum air temperature. Dwyer et al. (1990) also observed that average daily soil temperature at $5 \mathrm{~cm}$ depth were about 2.0 
and $1.5^{\circ} \mathrm{C}$ higher than corresponding minimum and maximum air temperatures, respectively. Toy et al. (1978) also found similar results in their experiment with different soil types and attributed the reasons to the 'low specific heat' and 'reduced air mixing' in soils than in air just above the soil surface. From Fig. 2, it was evident that in morning average daily soil temperature of surface soils at $5 \mathrm{~cm}$ depth was lowest, and it increased gradually with depth in subsurface soils (at 15 and $30 \mathrm{~cm}$ ) due to relatively faster cooling of surface soil during night time than subsurface soils when there was no energy source of solar radiation. Unlike morning, soil temperatures in afternoon followed the reverse trend with depths, because, with the progress of a day, heat transformation from direct solar radiation and advection of hot air increased surface soil temperature faster than its subsequent dissipation of heat to increase temperature in subsurface soil layers by conduction method of heat transmission. Similar trend was also observed in weekly and monthly data (data not shown). Kang et al. (2000) reported the similar results. For all the three soil depths weekly lowest temperatures in both the cases of morning and afternoon were found at $1 \mathrm{st}$ week except for $30 \mathrm{~cm}$ depth in morning where it was found at 2nd week (8-14 January). In morning at 5,15 , and $30 \mathrm{~cm}$ depths, weekly lowest minimum temperatures were $13.98,16.31$, and $19.25^{\circ} \mathrm{C}$, respectively, whereas, in afternoon the respective lowest temperatures were $23.57,19.48$, and $19.21^{\circ} \mathrm{C}$. Weekly highest temperature in morning at 5,15 , and $30 \mathrm{~cm}$ soil depths were observed at week number 23rd (4-10 June), 22nd (28 May - 3 June) and 20th (14-20 May), respectively, whereas, in afternoon for $5 \mathrm{~cm}$ depth it was observed at 16th week (16-22 April) and for 15 and $30 \mathrm{~cm}$ depths at 20th week. In the respective depths, the values were $29.56,30.80$, and $32.52^{\circ} \mathrm{C}$ in morning and $39.89,34.83$, and $32.44^{\circ} \mathrm{C}$ in afternoon. As heating (in day) and cooling (in night) process occurred through the surface soil, temperature in afternoon and morning generally fluctuated more at surface soil $(5 \mathrm{~cm})$ than subsurface soils $(15$ and $30 \mathrm{~cm}$ ), which was corroborated by the highest CV values of 10.43 in afternoon and 12.32 in morning at surface soil.

Monthly and annual minimum, maximum and mean air temperature data of 30 years (1985-2014) average along with their descriptive statistics were presented in Table 1 . This table showed that average monthly minimum $\left(10.82^{\circ} \mathrm{C}\right)$, maximum $\left(24.49^{\circ} \mathrm{C}\right)$, and mean $\left(17.66^{\circ} \mathrm{C}\right)$ air temperatures were lowest in January that appeared as the coolest month in a calendar year, and May was identified as the warmest month due to its highest maximum (35.09) and mean (30.15) temperatures. Similar findings about the hottest and coolest month were also observed at the same study site by analyzing 10 years (2001-2010) data (Barman et al., 2012). The fluctuation of minimum and mean air temperatures during last three decades (1985-2014) was highest in January, which was evident by highest $\mathrm{CV}$ values of $10.29 \%$ and $7.35 \%$, respectively; whereas for maxi- mum air temperature it was highest in February (Table 1). But for all three temperatures, minimum fluctuations was observed in July, which may be attributed to the monsoon rain. The trend analyses of time series weekly and monthly air temperature data were performed but only the results of monthly data were presented in Table 2. From this table, it was evident that a significant monotonically decreasing trend $\left(-0.018^{\circ} \mathrm{C}^{-1}\right)$ of minimum temperature has been detected in the month of August over the period of 19852014. In general, average minimum air temperature was in decreasing trend for most of the months but it was reverse in the case of maximum temperature. In trend analysis by taking weekly data (data not shown), significant monotonically decreasing trend of $-0.128,-0.028,-0.025,-0.070$ and $-0.061^{\circ} \mathrm{C}$ per year was observed in week number $2,33,34$, 44 and 52 , respectively, in the case of minimum temperature over the study period.

Mean monthly soil temperature data of 30 years at two fixed times (0636 IST and 1336 IST) for three soil depths $(5,15$ and $30 \mathrm{~cm})$ are presented in Table 3 . At all the three soil depths, minimum soil temperature was observed in January, and maximum was in May at both the times, which followed similar trend with corresponding values of the air temperatures. In morning (at 0636 IST) at 5, 15, and $30 \mathrm{~cm}$ soil depths, monthly minimum soil temperatures were $14.4,17.0$, and $19.1^{\circ} \mathrm{C}$; and maximum were $28.9,30.8$, and $31.8^{\circ} \mathrm{C}$, respectively. And, in afternoon ( at 1336 IST) at the same soil depths, minimum soil temperatures were 24.4, 20.2, and $19.1^{\circ} \mathrm{C}$; and maximum were 39.0, 34.6, and $32.2^{\circ} \mathrm{C}$, respectively. In general, average annual soil temperatures at 5,15 , and $30 \mathrm{~cm}$ soil depths were about $8.62,3.92$, and $0.17^{\circ} \mathrm{C}$ higher in afternoon than in morning, respectively at 5,15 and $30 \mathrm{~cm}$ soil depths. From the coefficients of variation in Table 3, it was evident that the fluctuation in average monthly soil temperatures at $5 \mathrm{~cm}$ depth in afternoon were higher than in morning, whereas it was generally reverse in the case of 15 and $30 \mathrm{~cm}$ soil depths. The results of the trend analysis of monthly soil temperatures over 30 years (1985-2014) were presented as Sen's slope and p-value in Table 4. In general at $5 \mathrm{~cm}$ depth, significant monotonically increasing and decreasing trends were observed in morning and afternoon, respectively.

Empirical models based on regression analysis were developed by taking 30 years averaged daily maximum and mean air temperature data with daily soil temperature data at 5,15 , and $30 \mathrm{~cm}$ depths for both morning and afternoon (Fig. 3). The purpose of using the long-term data in developing the models was to reduce bias in prediction and yearly variability in temperature due to climate and soil factors as suggested by Dwyer et al. (1990). It was observed that daily mean air temperature could be used to predict soil temperature in morning (0636 IST) by best fitted power model at $5 \mathrm{~cm}$ soil depth with $\mathrm{R}^{2}=0.993$; whereas, exponential models were best suited at 15 and $30 \mathrm{~cm}$ depths, with $R^{2}$ values of 0.997 and 0.993 , respectively. The 
T a b l e 1. Descriptive statistics of monthly minimum (Tmin), maximum (Tmax) and mean (Tmean) air temperature data (monthly average of 1985-2014) in Indo-Gangetic plain

\begin{tabular}{|c|c|c|c|c|c|c|c|c|c|c|c|c|c|}
\hline Statistics & Jan & Feb & Mar & Apr & May & Jun & Jul & Aug & Sep & Oct & Nov & Dec & Annual \\
\hline \multicolumn{14}{|c|}{$\operatorname{Tmin}\left({ }^{\circ} \mathrm{C}\right)$} \\
\hline Mean & 10.82 & 14.61 & 19.68 & 23.95 & 25.20 & 26.02 & 25.91 & 25.86 & 25.25 & 22.84 & 17.64 & 12.21 & 20.83 \\
\hline SD & 1.11 & 0.97 & 1.62 & 1.08 & 0.82 & 0.72 & 0.49 & 0.55 & 0.58 & 0.83 & 1.22 & 0.97 & 0.42 \\
\hline CV (\%) & 10.29 & 6.66 & 8.23 & 4.51 & 3.25 & 2.79 & 1.90 & 2.14 & 2.30 & 3.61 & 6.89 & 7.93 & 2.02 \\
\hline \multicolumn{14}{|c|}{$\operatorname{Tmax}\left({ }^{\circ} \mathrm{C}\right)$} \\
\hline Mean & 24.49 & 28.07 & 32.88 & 35.37 & 35.09 & 33.70 & 32.11 & 32.00 & 31.98 & 31.46 & 29.17 & 25.81 & 31.00 \\
\hline SD & 1.08 & 1.38 & 1.29 & 1.35 & 1.01 & 1.06 & 0.49 & 0.54 & 0.51 & 0.62 & 0.66 & 0.68 & 0.36 \\
\hline CV (\%) & 4.41 & 4.91 & 3.92 & 3.81 & 2.89 & 3.14 & 1.54 & 1.69 & 1.60 & 1.97 & 2.28 & 2.62 & 1.17 \\
\hline \multicolumn{14}{|c|}{ Tmean $\left({ }^{\circ} \mathrm{C}\right)$} \\
\hline Mean & 17.66 & 21.34 & 26.28 & 29.66 & 30.15 & 29.86 & 29.01 & 28.93 & 28.62 & 27.15 & 23.40 & 19.01 & 25.91 \\
\hline SD & 1.10 & 1.17 & 1.45 & 1.21 & 0.92 & 0.89 & 0.49 & 0.55 & 0.55 & 0.72 & 0.94 & 0.82 & 0.30 \\
\hline CV (\%) & 7.35 & 5.78 & 6.08 & 4.16 & 3.07 & 2.96 & 1.72 & 1.91 & 1.95 & 2.79 & 4.58 & 5.28 & 1.15 \\
\hline
\end{tabular}

T a b l e 2. Sen slope $(Q)\left({ }^{\circ} \mathrm{C}^{-1}\right)$ and $\mathrm{p}$ value $(\mathrm{p}=0.05)$ for the trend of Mann-Kendall test for monthly minimum, maximum, and mean air temperature over the period of 1985-2014

\begin{tabular}{lcccccc}
\hline \multirow{2}{*}{ Month } & \multicolumn{2}{c}{ Tmin } & \multicolumn{3}{c}{ Tmax } & \multicolumn{2}{c}{ Tmean } \\
\cline { 2 - 7 } January & $Q$ & $\mathrm{p}$ value & $Q$ & $\mathrm{p}$ value & $Q$ & $\mathrm{p}$ value \\
February & -0.011 & 0.761 & -0.037 & 0.101 & -0.025 & 0.253 \\
March & -0.014 & 0.655 & 0.000 & 1.000 & 0.008 & 0.735 \\
April & -0.007 & 0.844 & 0.022 & 0.326 & 0.009 & 0.789 \\
May & 0.000 & 1.000 & -0.005 & 0.957 & -0.004 & 0.915 \\
June & -0.008 & 0.668 & 0.018 & 0.411 & 0.005 & 0.748 \\
Julay & 0.003 & 0.802 & 0.018 & 0.422 & 0.011 & 0.617 \\
August & -0.001 & 0.844 & 0.006 & 0.485 & 0.003 & 0.579 \\
September & -0.018 & $0.012 *$ & 0.000 & 0.844 & -0.014 & 0.093 \\
October & -0.014 & 0.246 & 0.006 & 0.475 & -0.003 & 0.748 \\
November & -0.022 & 0.268 & -0.004 & 0.721 & -0.010 & 0.326 \\
December & -0.027 & 0.232 & 0.013 & 0.246 & -0.008 & 0.509 \\
\hline
\end{tabular}

* significant at 5\% level. 
T a b l e 3. Descriptive statistics of average monthly soil temperature data (monthly average of 1985-2014) at different depths in alluvial soils in Indo-Gangetic plain

\begin{tabular}{|c|c|c|c|c|c|c|c|c|c|c|c|c|c|}
\hline Statistics & Jan & Feb & Mar & Apr & May & Jun & Jul & Aug & Sep & Oct & Nov & Dec & $\begin{array}{l}\text { An- } \\
\text { nual }\end{array}$ \\
\hline \multicolumn{14}{|c|}{ Morning (0636 IST) } \\
\hline \multicolumn{14}{|c|}{ Depth $5 \mathrm{~cm}$} \\
\hline Mean & 14.36 & 18.00 & 23.55 & 27.62 & 28.88 & 28.90 & 27.89 & 27.71 & 27.33 & 25.24 & 20.33 & 15.38 & 23.77 \\
\hline SD & 1.00 & 1.04 & 1.15 & 1.48 & 1.38 & 0.87 & 0.64 & 1.09 & 0.61 & 0.87 & 1.18 & 0.86 & 0.51 \\
\hline CV (\%) & 6.98 & 5.77 & 4.90 & 5.37 & 4.77 & 2.99 & 2.29 & 3.92 & 2.22 & 3.46 & 5.78 & 5.59 & 2.13 \\
\hline \multicolumn{14}{|c|}{ Depth $15 \mathrm{~cm}$} \\
\hline Mean & 17.03 & 20.41 & 25.80 & 29.74 & 30.78 & 30.23 & 28.77 & 28.85 & 28.59 & 26.52 & 22.35 & 17.88 & 25.58 \\
\hline $\mathrm{SD}$ & 1.94 & 2.39 & 2.05 & 2.25 & 2.12 & 1.91 & 1.11 & 1.49 & 1.33 & 0.78 & 1.05 & 0.85 & 1.20 \\
\hline CV (\%) & 11.38 & 11.73 & 7.96 & 7.58 & 6.87 & 6.33 & 3.85 & 5.17 & 4.67 & 2.96 & 4.68 & 4.74 & 4.68 \\
\hline \multicolumn{14}{|c|}{ Depth $30 \mathrm{~cm}$} \\
\hline Mean & 19.14 & 22.29 & 27.17 & 30.75 & 31.85 & 31.11 & 29.70 & 29.64 & 29.59 & 28.37 & 24.88 & 21.20 & 27.14 \\
\hline SD & 0.74 & 0.89 & 1.07 & 1.46 & 1.11 & 0.98 & 0.60 & 1.24 & 0.52 & 0.70 & 0.81 & 2.41 & 0.40 \\
\hline CV (\%) & 3.84 & 4.00 & 3.93 & 4.74 & 3.47 & 3.16 & 2.03 & 4.19 & 1.75 & 2.47 & 3.25 & 11.38 & 1.49 \\
\hline \multicolumn{14}{|c|}{ Afternoon (1336 IST) } \\
\hline \multicolumn{14}{|c|}{ Depth $5 \mathrm{~cm}$} \\
\hline Mean & 24.36 & 28.96 & 35.38 & 38.86 & 39.00 & 35.71 & 33.27 & 33.28 & 33.35 & 32.29 & 28.88 & 25.31 & 32.39 \\
\hline SD & 1.82 & 1.86 & 1.92 & 2.29 & 2.13 & 1.75 & 0.84 & 1.44 & 1.45 & 1.08 & 1.01 & 2.17 & 0.81 \\
\hline $\mathrm{CV}(\%)$ & 7.47 & 6.43 & 5.43 & 5.90 & 5.47 & 4.89 & 2.53 & 4.33 & 4.35 & 3.33 & 3.49 & 8.58 & 2.50 \\
\hline \multicolumn{14}{|c|}{ Depth $15 \mathrm{~cm}$} \\
\hline Mean & 20.18 & 24.04 & 29.82 & 33.68 & 34.57 & 32.94 & 30.90 & 30.76 & 30.87 & 32.22 & 28.79 & 25.21 & 29.50 \\
\hline SD & 1.04 & 1.44 & 1.49 & 1.78 & 1.40 & 1.42 & 0.54 & 0.97 & 0.84 & 1.17 & 1.20 & 2.30 & 0.42 \\
\hline CV (\%) & 5.15 & 5.98 & 5.01 & 5.29 & 4.06 & 4.31 & 1.76 & 3.14 & 2.70 & 3.63 & 4.17 & 9.13 & 1.44 \\
\hline \multicolumn{14}{|c|}{ Depth $30 \mathrm{~cm}$} \\
\hline Mean & 19.14 & 22.55 & 27.25 & 30.72 & 32.18 & 31.37 & 29.98 & 29.90 & 29.78 & 28.69 & 24.96 & 21.23 & 27.31 \\
\hline SD & 1.01 & 0.89 & 1.17 & 2.28 & 1.00 & 1.12 & 0.53 & 1.00 & 0.59 & 0.73 & 0.75 & 2.01 & 0.40 \\
\hline $\mathrm{CV}(\%)$ & 5.29 & 3.95 & 4.30 & 7.43 & 3.12 & 3.56 & 1.76 & 3.36 & 2.00 & 2.56 & 3.01 & 9.45 & 1.48 \\
\hline
\end{tabular}

$\mathrm{R}^{2}$ values showed that the prediction of soil temperatures using mean air temperature could explain more than $99 \%$ variability of soil temperatures for all three depths in morning. While precision in prediction of soil temperatures in afternoon (1336 IST) increased when daily maximum air temperatures were used in an exponential model for $5 \mathrm{~cm}$ soil depth, and power model for $15 \mathrm{~cm}$ depth; however, for $30 \mathrm{~cm}$ depth daily mean air temperatures rather than maximum air temperature, were best fitted to the exponential model to predict soil temperatures in afternoon. The variability in predicted soil temperatures by the developed models could be explained more than $97 \%$ at 5 and $15 \mathrm{~cm}$ soil depths, and $99 \%$ at $30 \mathrm{~cm}$ depth, which was evident by corresponding $\mathrm{R}^{2}$ values of $0.978,0.971$ and 0.993 . The lower and upper limits of confidence interval (at 95\% level) of the predicted soil temperatures were computed statistically and presented in Fig. 4. Data showed that all the predicted soil temperature values were bounded within the limits of $95 \%$ confidence interval.

Prediction of weekly soil temperatures from weekly air temperature data was performed to understand the variability of soil temperatures, which is required for ecosystem management. Like daily data, regression analysis was carried out with average weekly air temperature, and soil 
T a b l e 4. Sen slope $(Q)\left({ }^{\circ} \mathrm{C}^{-1}\right)$ and $\mathrm{p}$ value $(\mathrm{p}=0.05)$ of Mann-Kendall test for monthly soil temperature at 0636 and 1336 IST for 5,15 , and $30 \mathrm{~cm}$ soil depths in study site over the period of 1985-2014

\begin{tabular}{|c|c|c|c|c|c|c|c|c|c|c|c|c|}
\hline \multirow{4}{*}{ Month } & \multicolumn{12}{|c|}{ Depth (cm) } \\
\hline & \multicolumn{4}{|c|}{5} & \multicolumn{4}{|c|}{15} & \multicolumn{4}{|c|}{30} \\
\hline & \multicolumn{2}{|c|}{$0636 \mathrm{~h}$} & \multicolumn{2}{|c|}{$1336 \mathrm{~h}$} & \multicolumn{2}{|c|}{$0636 \mathrm{~h}$} & \multicolumn{2}{|c|}{$1336 \mathrm{~h}$} & \multicolumn{2}{|c|}{$0636 \mathrm{~h}$} & \multicolumn{2}{|c|}{$1336 \mathrm{~h}$} \\
\hline & $Q$ & $\mathrm{p}$ value & $Q$ & $\mathrm{p}$ value & $Q$ & $\mathrm{p}$ value & $Q$ & $\mathrm{p}$ value & $Q$ & $\mathrm{p}$ value & $Q$ & $\mathrm{p}$-value \\
\hline Jan & 0.027 & 0.292 & $-0.103 *$ & 0.006 & -0.033 & 0.205 & -0.028 & 0.284 & -0.024 & 0.309 & $-0.040 *$ & 0.018 \\
\hline Feb & 0.006 & 0.803 & -0.065 & 0.232 & -0.033 & 0.326 & -0.009 & 0.748 & -0.002 & 0.886 & -0.021 & 0.401 \\
\hline Mar & 0.037 & 0.090 & -0.031 & 0.344 & -0.001 & 0.915 & 0.056 & 0.138 & 0.016 & 0.422 & -0.014 & 0.544 \\
\hline Apr & 0.038 & 0.143 & 0.019 & 0.775 & 0.010 & 0.858 & 0.040 & 0.276 & 0.046 & 0.164 & 0.053 & 0.129 \\
\hline May & $0.060^{*}$ & 0.047 & -0.018 & 0.816 & 0.010 & 0.748 & $0.087 *$ & 0.007 & 0.014 & 0.630 & 0.010 & 0.655 \\
\hline Jun & $0.041^{*}$ & 0.027 & 0.016 & 0.580 & 0.018 & 0.486 & 0.036 & 0.164 & 0.020 & 0.353 & 0.013 & 0.412 \\
\hline Jul & $0.034 *$ & 0.002 & -0.010 & 0.668 & $0.018^{*}$ & 0.038 & $0.025^{*}$ & 0.039 & 0.017 & 0.186 & 0.009 & 0.442 \\
\hline Aug & $0.037^{*}$ & 0.001 & -0.011 & 0.695 & 0.008 & 0.497 & 0.029 & 0.083 & 0.010 & 0.284 & 0.014 & 0.292 \\
\hline Sep & $0.036^{*}$ & 0.002 & -0.007 & 0.695 & 0.014 & 0.116 & 0.018 & 0.174 & 0.000 & 0.929 & -0.001 & 0.680 \\
\hline Oct & $0.041^{*}$ & 0.046 & $-0.060 *$ & 0.032 & 0.000 & 0.957 & $-0.076^{*}$ & 0.014 & 0.003 & 0.844 & 0.000 & 0.957 \\
\hline Nov & 0.047 & 0.134 & $-0.063 *$ & 0.005 & -0.011 & 0.642 & $-0.078 *$ & 0.003 & -0.014 & 0.531 & -0.013 & 0.421 \\
\hline Dec & 0.032 & 0.148 & -0.105 & $<0.001$ & -0.033 & 0.068 & $-0.123^{*}$ & $<0.001$ & -0.014 & 0.432 & -0.020 & 0.211 \\
\hline
\end{tabular}

*significant at $5 \%$ level.

temperatures at 5,15 , and $30 \mathrm{~cm}$ depths in morning $(0636$ IST) and afternoon (1336 IST) (Fig. 5). In morning, highest $\mathrm{R}^{2}$ values were found when mean air temperatures were correlated with soil temperatures at all three depths. Moreover, the power function models were best fitted at $5 \mathrm{~cm}$ $\left(\mathrm{R}^{2}=0.994\right)$ and $15 \mathrm{~cm}\left(\mathrm{R}^{2}=0.997\right)$ soil depths, whereas the exponential model at $30 \mathrm{~cm}\left(\mathrm{R}^{2}=0.993\right)$. But in afternoon, soil temperatures at 5,15 , and $30 \mathrm{~cm}$ depths were highly correlated with maximum air temperature by exponential model $\left(\mathrm{R}^{2}=0.989\right)$, mean temperature by power function model $\left(\mathrm{R}^{2}=0.985\right)$, and mean temperature by exponential model $\left(\mathrm{R}^{2}=0.992\right)$, respectively. For both the times, these models by using only air temperature could explain more than $99 \%$ variability in soil temperature at all three depths.

Monthly soil temperatures simulated from air temperature data are used as an input variable in many simulation models like CENTURY (Parton, 1996), RothC (Coleman and Jenkinson, 1996), and DNDC (Li, 1996). For site specific calibration and validation of these models, development of regression models is necessary. Toy et al. (1978) developed regression model to predict monthly soil temperature from monthly air temperature data, and suggested to develop such regional model at various depths for greater accuracy. The regression analysis was, therefore, performed by taking 30 years averaged monthly air temperature, and soil temperature data at 5,15 , and $30 \mathrm{~cm}$ soil depths
(Fig. 6). Similar to weekly regression analysis, monthly soil temperatures at all three depths in morning were highly correlated with mean air temperature, and power model was best fitted at $5 \mathrm{~cm}$ with $\mathrm{R}^{2}$ of 0.996 , exponential models at 15 and $30 \mathrm{~cm}$ depths with $\mathrm{R}^{2}$ of 0.999 and 0.992 , respectively. However, in afternoon, using maximum air temperature gave best fitted exponential model $\left(R^{2}=0.990\right)$ at $5 \mathrm{~cm}$, and logarithmic model $\left(\mathrm{R}^{2}=0.901\right)$ at $15 \mathrm{~cm}$ depth. But at $30 \mathrm{~cm}$, using mean air temperature gave best fitted power model $\left(\mathrm{R}^{2}=0.992\right)$. For all the cases, the prediction models can explain more than $99 \%$ variability using average air temperature data except for $15 \mathrm{~cm}(\sim 90 \%)$ in afternoon, which might be due to soil moisture content and the logarithmic relationship.

During night time the surface soil dissipated heat energy and in morning it became almost in equilibrium with air temperature (Parton and Logan, 1981), therefore, at $5 \mathrm{~cm}$ we obtained the best fitted power function model for daily data. But in afternoon the best fitted models were exponential because from sunrise to mid-day, it was observed that initially the rate of increase of air and surface soil temperature was slow, but thereafter it increased in a faster rate in silty loam soil (sand $26.04 \%$, silt $56.16 \%$, clay $7.80 \%$ ). But at $15 \mathrm{~cm}$ depth in loam soil, (sand $42.04 \%$, silt $36.08 \%$, clay $21.88 \%$ ) they were reverse in morning as well as in afternoon, which might be attributed to the slow upward 

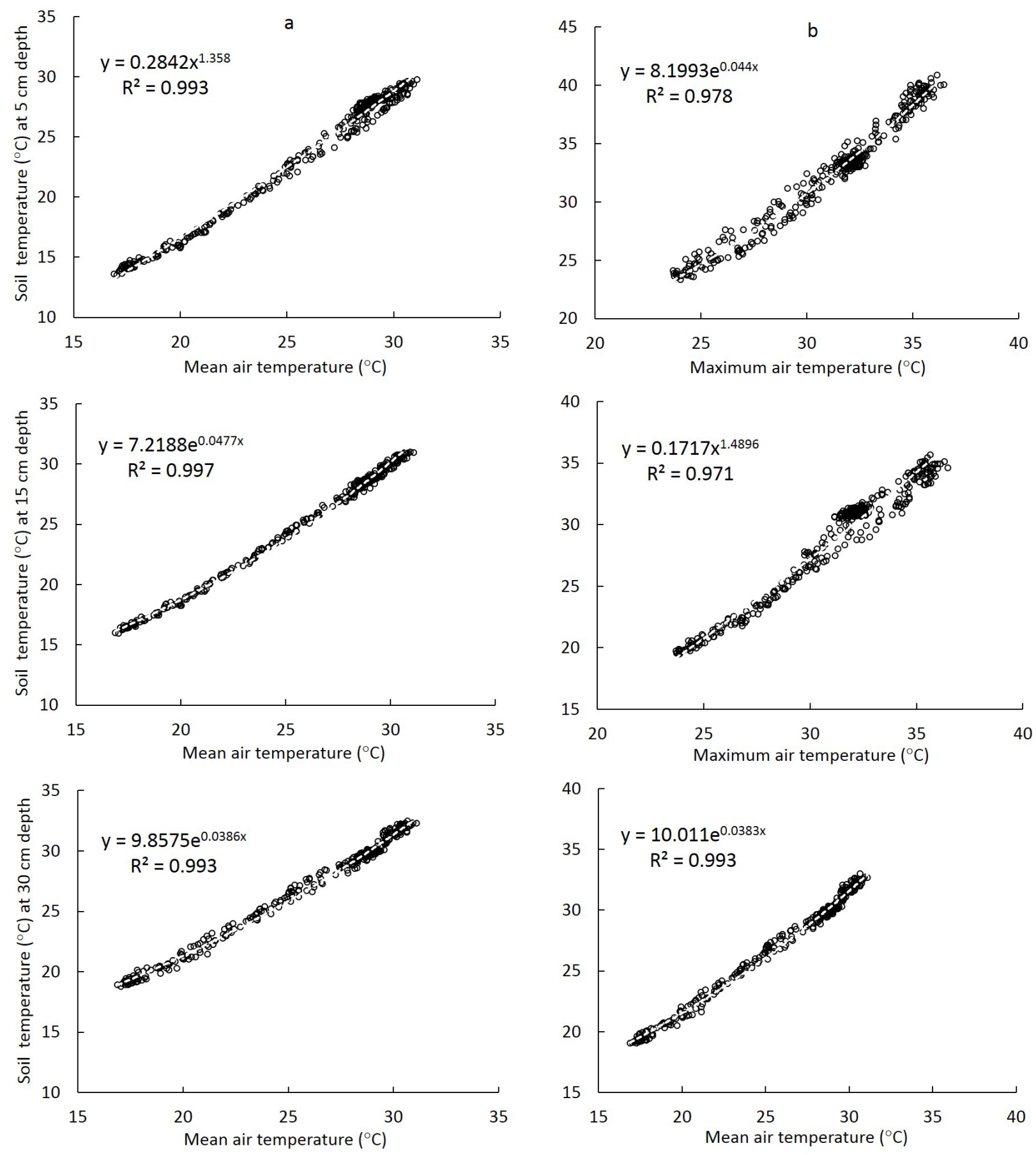

Fig. 3. Prediction of daily soil temperatures at 5, 15, and $30 \mathrm{~cm}$ depths in: a - morning and b-afternoon using daily air temperature data for alluvial soils in lower Indo-Gangetic plain.

heat transmission in the case of former due to the limited heat supply from lower soil layer but it was faster in latter due to constant heat supply chain from solar radiation to the adjacent surface soil layer. However, at $30 \mathrm{~cm}$ soil depth in sandy loam soil (sand $49.96 \%$, silt $26.08 \%$, clay $23.96 \%$ ), exponential functions depicted the general decay of heat energy for upward and downward directions in morning and afternoon, respectively.
Recently surface soil temperature at unknown locations have been predicted by interpolating measured surface soil temperatures (Kang et al., 2000; Liang et al., 2013). But its relation with sub-soil temperature needs to be studies for better soil profile management in respect to crop growth. The empirical models, therefore, were developed by taking 30 years average daily soil temperatures at surface $(5 \mathrm{~cm})$ and sub-surface $(15$ and $30 \mathrm{~cm})$ soils and presented in Fig. 7. Soil temperatures at $5 \mathrm{~cm}$ depth in morning 

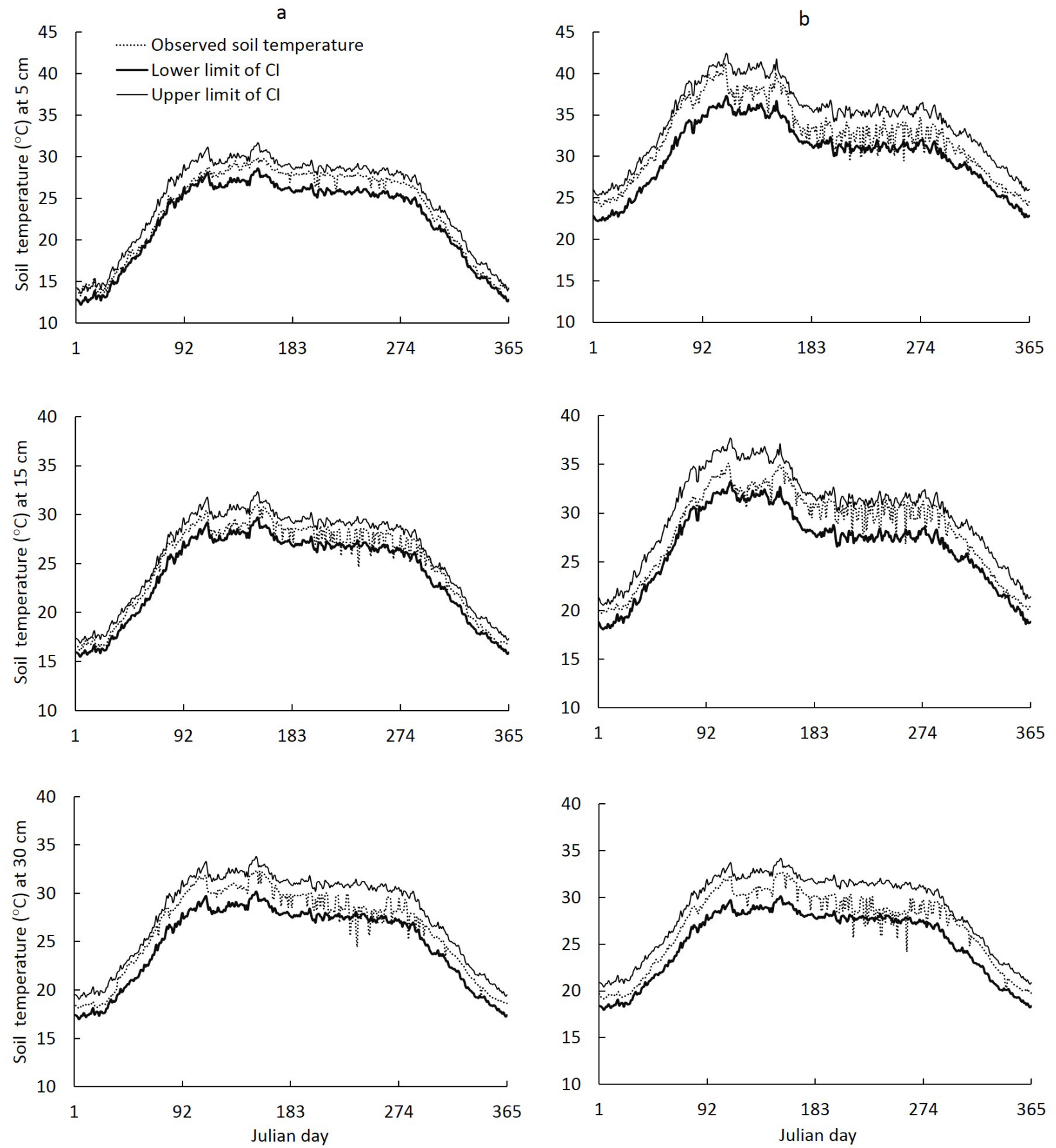

Fig. 4. Comparison between daily observed, and lower and upper limit of predicted soil temperature at 5, 15 , and $30 \mathrm{~cm}$ soil depths in: $\mathrm{a}$ - morning (0636 IST) and b - afternoon (1336 IST) at 95\% confidence interval (CI). Daily soil temperatures at all three depths were predicted using daily air temperature data.

was highly correlated at 15 and $30 \mathrm{~cm}$ soil depths having a power function relationship with $\mathrm{R}^{2}$ values of 0.996 and 0.989 , respectively. But in afternoon, logarithmic regression models showed better correlation between $5 \mathrm{~cm}$, and 15 and $30 \mathrm{~cm}$ soil temperature data. In morning irrespective of soil factors like texture and moisture, temperature in soil profile became equilibrium, and therefore, power function relationship was developed. However, surface soil due to its low clay $(7.80 \%)$ and moisture content is heated faster by direct solar radiation and advection from hot wind in afternoon, but vertical conduction of heat from surface soil increased sub-soil temperature slowly due to comparatively higher clay $(21.88 \%$ at $15 \mathrm{~cm}$, and $23.96 \%$ at $30 \mathrm{~cm})$ and moisture content in the subsequent layers. The influence of 

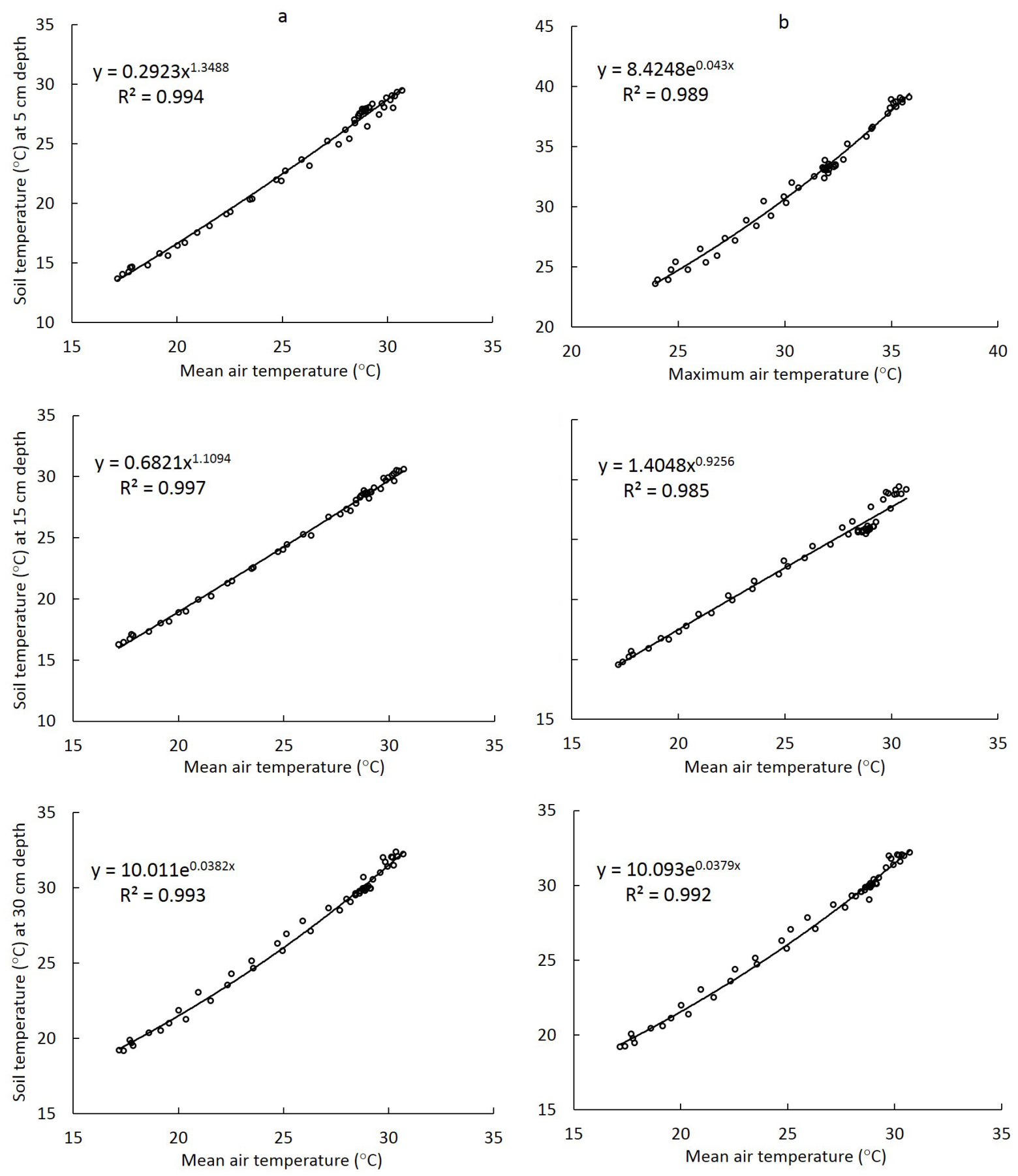

Fig. 5. Prediction of weekly soil temperatures at 5, 15, and $30 \mathrm{~cm}$ depths in: a-morning (0636 IST) and b-afternoon (1336 IST) using weekly air temperature data for alluvial soils in lower Indo-Gangetic.

these soil properties on thermal conduction and convection processes in soil was reported by Gao et al. (2003). This led to develop logarithmic relationship in afternoon. The lower and upper limits of confidence interval (at 95\% level) of the predicted soil temperatures at 15 and $30 \mathrm{~cm}$ soil depths were computed and presented in Fig. 8. It was evident from the Fig. 8 that all the predicted soil temperature values were bounded within the limits of $95 \%$ confidence interval.

\section{CONCLUSIONS}

1. In general, temperature in alluvial soils increased with soil depth up to $30 \mathrm{~cm}$ in morning but the trend was reverse in afternoon. The long-term (1985-2014) average minimum and maximum temperatures at $5 \mathrm{~cm}$ depth were found higher than corresponding air temperatures.

2. Regression analysis revealed that daily, weekly, and monthly morning soil temperature up to $30 \mathrm{~cm}$ depth in alluvial soils could be predicted efficiently using 
a
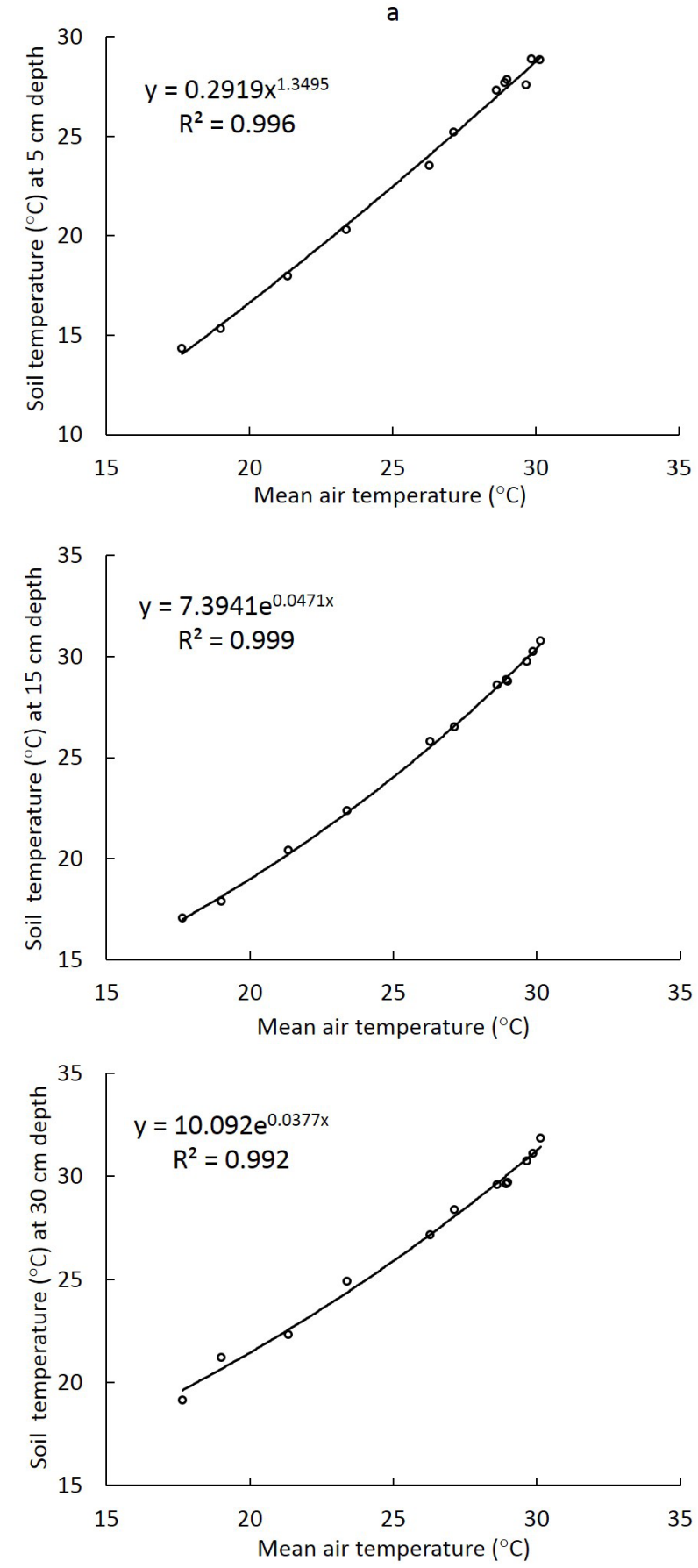
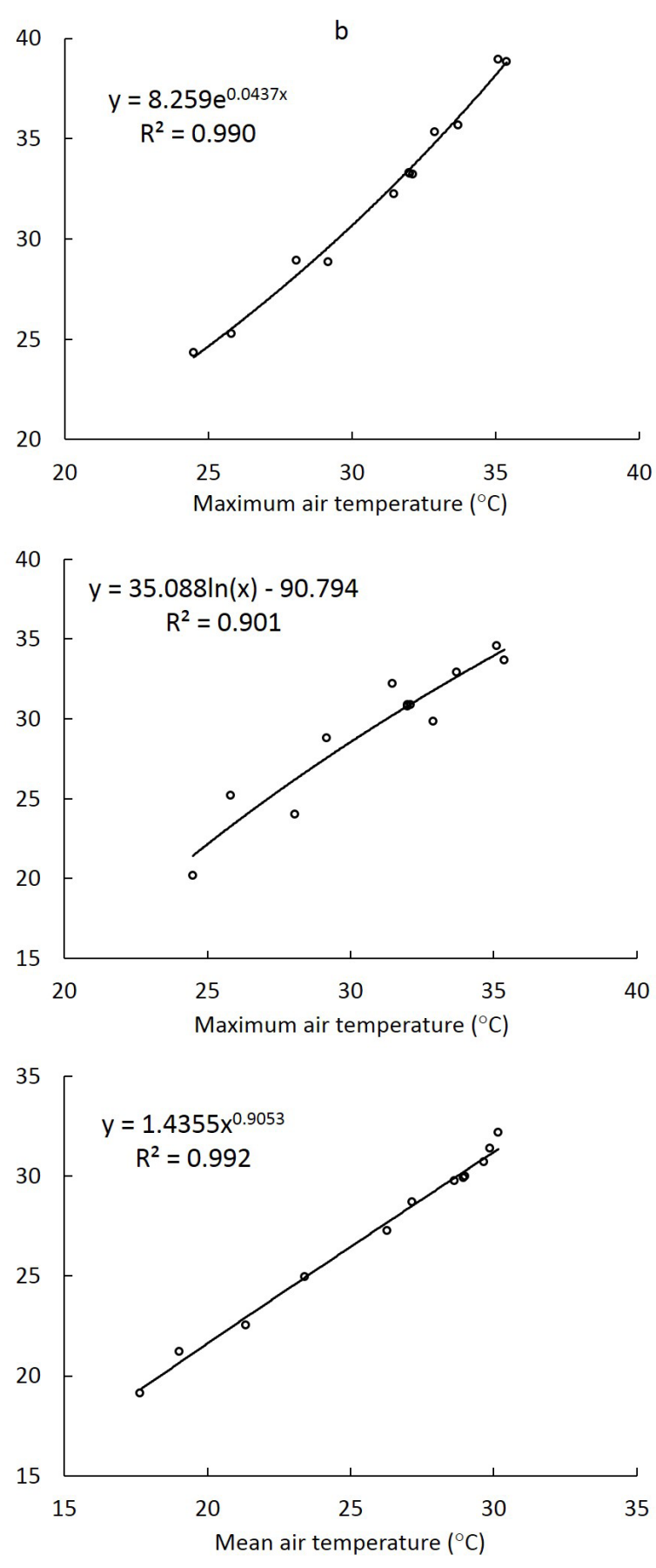

Fig. 6. Prediction of monthly soil temperatures at 5, 15 and $30 \mathrm{~cm}$ depths in: a-morning (0636 IST) and b-afternoon (1336 IST) using monthly air temperature data for alluvial soils in lower Indo-Gangetic plain.

correspondingmeanairtemperature. Whileusingofmaximum air temperature is suggested for afternoon soil temperature prediction up to $15 \mathrm{~cm}$ soil depth, beyond which (up to $30 \mathrm{~cm}$ ) mean air temperature would give better prediction.

3. Empirical models were also developed to predict daily sub-soil temperature (at 15 and $30 \mathrm{~cm}$ depths) using long-term average daily surface soil temperature (at $5 \mathrm{~cm}$ ). While air temperature data are scarce, these models could be used to derive sub-soil temperature where surface soil temperatures are known or could be derived by methods like interpolation in spatial tools, viz. remote sensing and geographic information system (GIS).

4. Although the coefficients and constants were estimated for only one site, but considering the long-term data in this study, the general method/models of estimating soil temperature could be applicable to other sites in similar ecologies with little bit of site specific modification. 

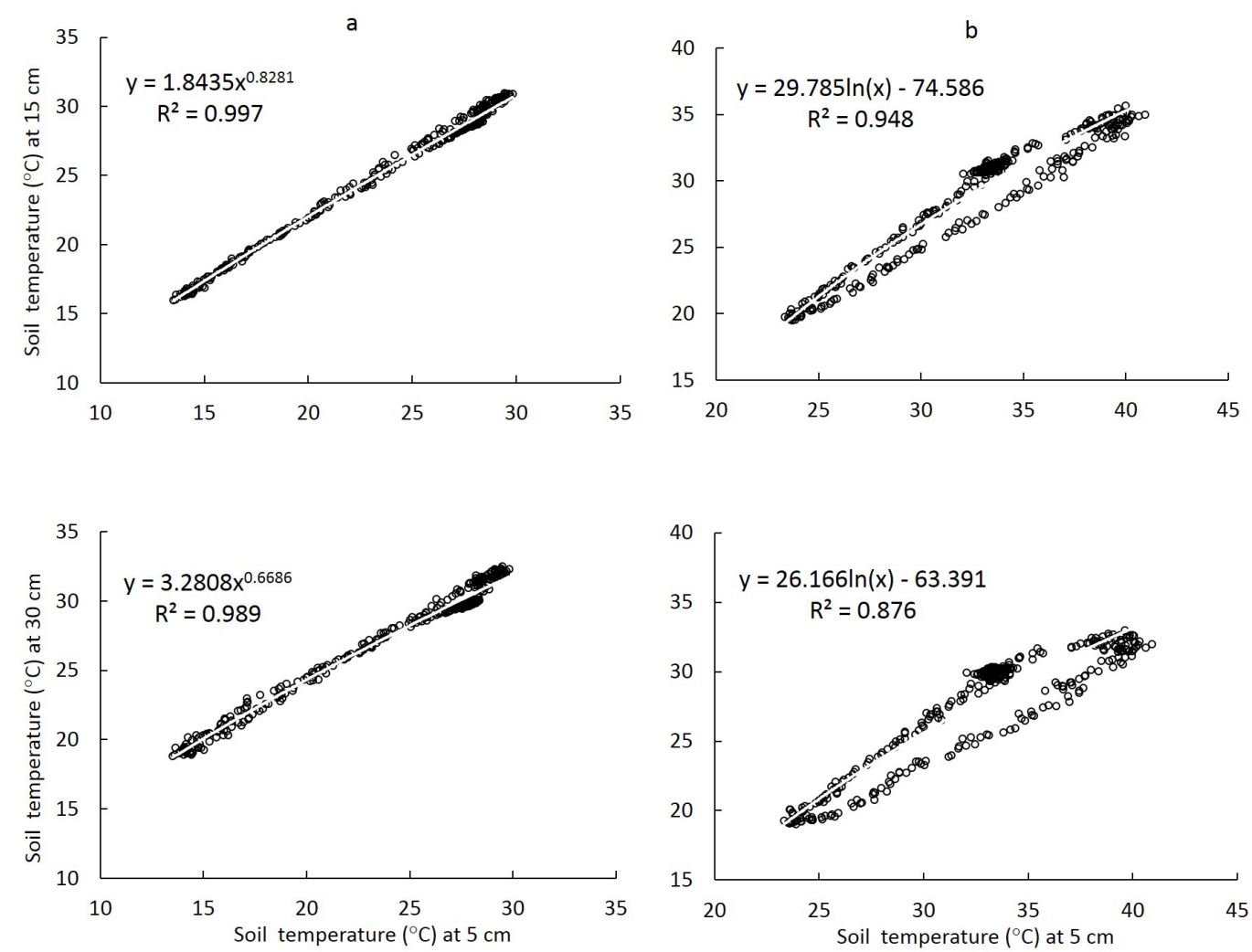

Fig. 7. Prediction of daily sub-soil temperature at 15 and $30 \mathrm{~cm}$ depths using surface soil temperature data at $5 \mathrm{~cm}$ in: a - morning ( 0636 IST) and b-afternoon (1336 IST) for alluvial soils in lower Indo-Gangetic plain.
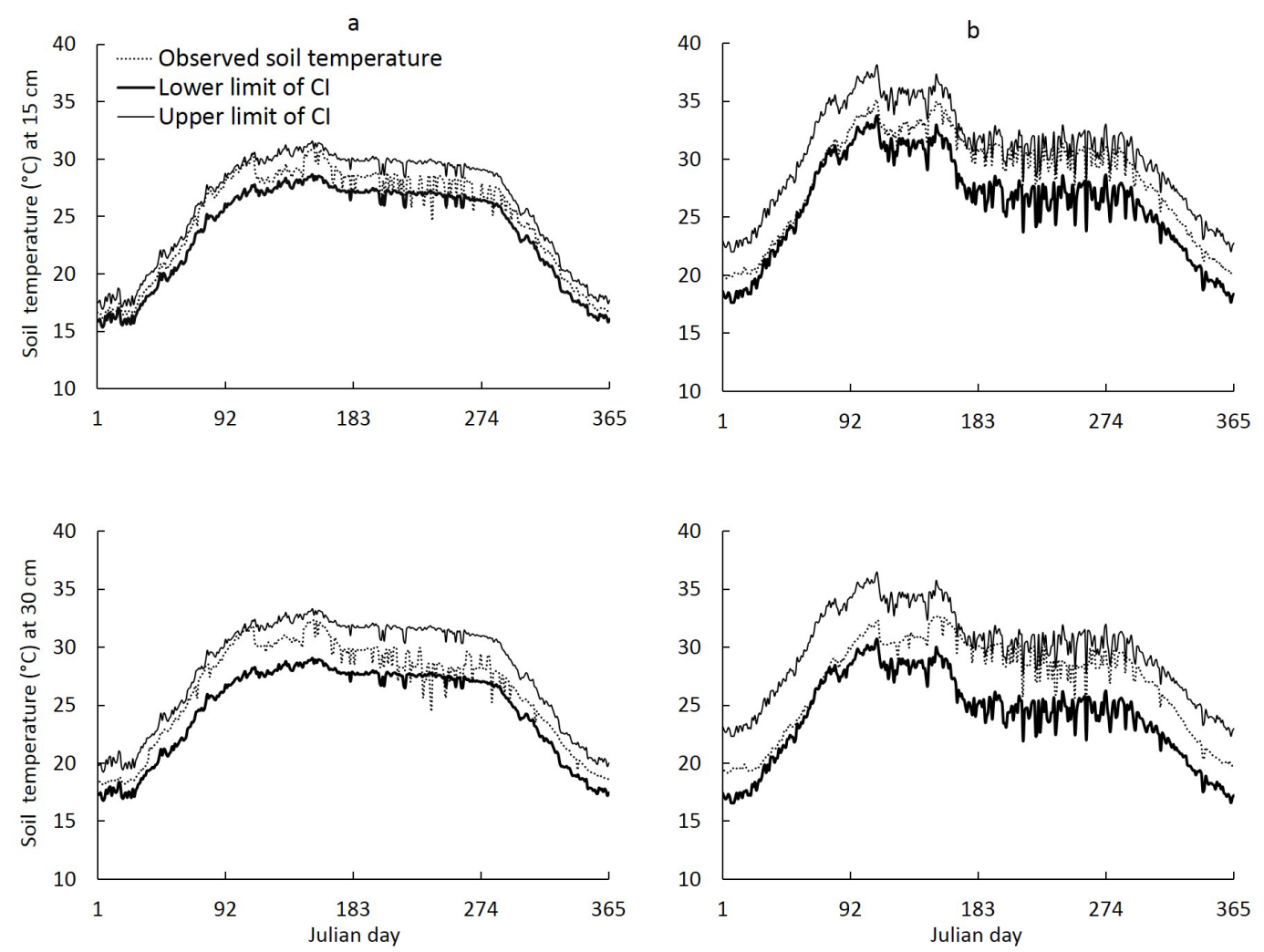

Fig. 8. Comparison between daily observed, and lower and upper limit of predicted soil temperature at 15 and $30 \mathrm{~cm}$ soil depths in: $\mathrm{a}$ - morning (0636 IST) and b - afternoon (1336 IST) at 95\% confidence interval (CI). Daily soil temperatures at both the depths were predicted using surface soil temperature data at $5 \mathrm{~cm}$. 
5. These models after validation at multiple locations can be used to predict depth wise soil temperatures for various purposes, which has a greater implication in developing methodologies in space technology like remote sensing for upscaling or downscaling.

\section{ACKNOWLEDGEMENTS}

The authors wish to acknowledge technical assistance rendered by Sh. Sudhir Sarkar, Asst. Chief Technical Officer in compilation of data. Encouragement by the Director, ICAR-CRIJAF, Barrackpore is acknowledged by the team.

Conflict of interest: Authors have no conflict of interest to declare.

\section{REFERENCES}

Barman D., Kundu D.K., Saha A.R., and Mahapatra B.S., 2012. Rainfall characteristics analysis for jute based cropping system at Barrackpore, West Bengal, India. J. Agril. Phys., 12(1), 23-28.

Bouyoucos G.J., 1962. Hydrometer method improved for making particle size analysis of soils. Agronomy J., 54, 464-465.

Brenna S., Riparbelli C., Costantini E., L'Abate G., and Percich L., 2002. Soil moisture and temperature regimes in Lombardy (Northern Italy). In: Sustainable use and management of soils in arid and semiarid regions (Eds A. Faz, R. Ortiz, A.R. Mermut). ISBN: 84-95383-23-3, vol. 2, 23-24.

Burton A.J., Pregitzer K.S., Zogg G.P., and Zak D.R., 1998. Drought reduces root respiration in sugar maple forests. Ecological Applications, 8(3), 1998, 771-778.

Coleman K. and Jenkinson D.S., 1996. RothC-26.3- A model for the turnover of carbon in soil. In: Evaluation of soil organic matter models using existing long-term datasets (Eds D.S. Powlson, P. Smith, J.U. Smith). NATO ASI Series I, 38, 237-246.

Davidson E.A. and Janssens I.A., 2006. Temperature sensitivity of soil carbon decomposition and feedbacks to climate change. Nature, 440, 165-173.

Domisch T., Finér L., and Lehto T., 2001. Effects of soil temperature on biomass and carbohydrate allocation in Scots pine (Pinus sylvestris) seedlings at the beginning of the growing season. Tree Physiology, 21, 465-472.

Dwyer L.M., Hayhoe H.N., and Culley J.L.B., 1990. Prediction of soil temperature from air temperature for estimating corn emergence. Can. J. Plant Sci., 70, 619-628.

Euskirchen E., McGuire A.D., Kicklighter D.W., Zhuang Q., Clein J.S., Dargaville R.J., Dye D.G., Kimball J.S., McDonald K.C., Melillo J.M., Romanovsky V.E., and Smith N.V., 2006. Importance of recent shifts in soil thermal dynamics on growing season length, productivity, and carbon sequestration in terrestrial high latitude eco-systems. Global Change Biology, 12, 731-750.

Gao Z., Fan X., and Bian L., 2003. An analytical solution to onedimensional thermal conduction-convection in soil. Soil Sci., 168(2), 99-107.
Gislason S.R., Oelkers E.H., Eiriksdottir E.S., Kardjilov M.I., Gisladottir G., Sigfusson B., Snorrason, A., Elefsen S., Hardardottir, J., Torssander P., and Oskarsson N., 2009. Direct evidence of the feedback between climate and weathering. Earth and Planetary Science Letters, 277, 213-222.

Grundmann G.L., Renault P., Rosso L., and Bardin R., 1995. Differential effects of soil water content and temperature on nitrification and aeration. Soil Sci. Soc. Am. J., 59, 1342-1349.

Gupta S.C., Larson W.E., and Linden D.R., 1983. Tillage and surface residue effects on soil upper boundary temperatures. Soil Sci. Soc. Am. J., 47, 1212-1218.

Haei M., O“quist M.G., Buffam I., A ${ }^{\circ}$ gren A., Blomkvist P., Bishop K., Löfvenius M.O., and Laudon H., 2010. Cold winter soils enhance dissolved organic carbon concentrations in soil and stream water. Geophysical Research Letters, 37.

Haei M, O“quist M.G., Kreyling J., Ilstedt U., and Laudon H., 2013. Winter climate controls soil carbon dynamics during summer in boreal forests. Environmental Research Letters, 8, 024017.

Hasfurther V.R. and Burman R.D., 1974. Soil temperature modeling using air temperature as a driving mechanism. Trans. Am. Soc. Agric. Eng., 16, 78-81.

Jungqvist G., Oni S.K., Teutschbein C., and Futter M.N., 2014. Effect of climate change on soil temperature in Swedish boreal forests. PLoS ONE 9(4): e93957. doi:10.1371/ journal.pone. 0093957.

Kang S., Kim S., Oh S., and Lee D., 2000. Predicting spatial and temporal patterns of soil temperature based on topography, surface cover and air temperature. Forest Ecol. Manag., 136, 173-184.

Kaspar T.C. and Bland W.L., 1992. Soil temperature and root growth, (USA). Soil Science, 154(4), 290-297.

Kendall M.G., 1975. Rank Correlation Methods. Charles Griffin, London.

Kluender R.A., Thompson L.C., and Steigrwald D.M., 1993. A conceptual model for predicting soil temperatures. Soil Sci. (Philadelphia), 156, pp-10-19.

Kumar A., Chattopadhyay C., Singh K.N., Vennila S., and Rao V., 2014. Trend analysis of climatic variables in Pegionpea growing regions in India. MAUSAM, 65(2), 161-170.

Leirós M.C., Trasar-cepeda C., Seoane S., and Gil-Sotres F., 1999. Dependence of mineralization of soil organic matter on temperature and moisture. Soil Biol. Biochem., 31, 327-335.

Li C., 1996. The DNDC model. In: Evaluation of soil organic matter models using existing long-term datasets (Eds D.S. Powlson, P. Smith, J.U. Smith). NATO ASI Series I, 38, 263-268.

Liang L.L., Riverros-iregui D.A., Emanuel R.E., and McGlynn B.L., 2014. A simple framework to estimate distributed soil temperature from discrete air temperature measurements in data-scarce regions. J. Geophys. Res. Atmos., 119, 1-11.

Mann H.B., 1945. Nonparametric tests against trend. Econometrica, 13(3), 245-259. 
McCann I.R., McFarland M.J., and Witz J.A., 1991. Nearsurface bare soil temperature model for biophysical models, Trans. Am. Soc. Agric. Eng., 34, 748-755.

Melillo J.M., Steudler P.A., Aber J.D., Newkirk K., Lux H., Bowles F.P., Catricala C., Magill A., Ahrens T., Morrisseau S., 2002. Soil warming and carbon-cycle feedbacks to the climate system. Science, 298(5601), 2173-6.

Merdun H., 2012. Effects of different factors on water flow and solute transport investigated by time domain reflectometry in sandy clay loam field soil. Water Air Soil Pollut., 223:4905 - 4923, DOI 10.1007/s11270-012-1246-x.

Oquist M. and Laudon H., 2008. Winter soil frost conditions in boreal forests control growing season soil $\mathrm{CO}_{2}$ concentration and its atmospheric exchange. Global Change Biology, 14, 2839-2847.

Pal S., Mazumdar D., and Chakraborty P.K., 2015. Districtwise trend analysis of rainfall pattern in last century (1901-2000) over Gangetic region in West Bengal, India. J. Applied Natural Sci., 7(2), 750-757.

Parton W.J., 1996. The CENTURY model. In: Evaluation of soil organic matter models using existing long-term datasets (Eds D.S. Powlson, P. Smith, J.U. Smith). NATO ASI Series I, 38, 283-293.

Parton W.J. and Logan J.A., 1981. A model for diurnal variation in soil and air temperature. Agricultural Meteorology, 23, 205-216.

Ren J., Shen Z., Yang J., Zhao J., and Yin J., 2014. Effects of temperature and density on hydraulic conductivity of silty clay under infiltration of low-temperature water. Arab. J. Sci. Eng., 39, 461-466. DOI10.1007/s13369-013-0849-x.

Rustad L.E., Campbell J.L., Marion G.M., Norby R.J., Mitchell M.J., Hartley A.E., Cornelissen J.H.C., and Gurevitch J., 2001. A meta-analysis of the response of soil respiration, net nitrogen mineralization, and above ground plant growth to experimental ecosystem warming. Oecologia, 126, 543-562, doi: 10.1007/s004420000544

Scheffer F., Schachtschabel P., and Blume H.P., 2002. Lehrbuch der Bodenkunde. 15. Aufl. edition. Spektrum Akademischer Verlag, Heidelberg.

Sen P.K., 1968. Estimates of the regression coefficient based on Kendall's Tau. J. Am. Stat. Assoc., 63, 1379-1389.

Singh V.P., 1992. Elementary hydrology. Prentice-Hall, Englewood Cliffs, NJ, USA.

Soil Survey Staff, 1999. Soil Taxonomy: A Basic System of Soil Classification for Making and Interpreting Soil Surveys, Second Edition. Agriculture Handbook, No. 436. Natural Resources Conservation Service, United States Department of Agriculture, Washington, DC, USA.

Stromgren M. and Linder S., 2002. Effects of nutrition and soil warming on stem wood production in a boreal Norway spruce stand. Global Change Biology, 8, 1194-120.

Theil H., 1950. A rank-invariant method of linear and polynomial regression analysis (parts 1-3). Ned. okad. Wetensch. Proc. ser. A, 53, 386-392, 521-525, 1397-1412.

Toy T.J., Kuhaida A.J., and Munson, B.E., 1978. The prediction of mean monthly soil temperature from mean monthly air temperature. Soil Sci., 126, 181-189.

Vigil M.F. and Kissel D.E., 1995. Rate of nitrogen mineralized from incorporated crop residues as influenced by temperature, Soil Sci. Soc. Am. J., 59, 1636-1644.

Zhang Y., Chen W., Smith S.L., Riseborough D.W., and Cihlar J., 2005. Soil temperature in Canada during the twentieth century: Complex responses to atmospheric climate change. J. Geophys. Res., 110, D03112, doi:10.1029/2004JD004910.

Zheng D., Hunt E.R. Jr., and Running S.W., 1993. A daily soil temperature model based on air temperature and precipitation for continental application, Clim. Res., 2, 183-191. 